\title{
Antioxidant Activities of Eucheuma sp. (Rhodophyceae) and Laminaria sp. (Phaeophyceae) $)^{\#}$
}

\author{
İlknur Ak ${ }^{1, a, *}$, Gülen Türker ${ }^{2, b}$ \\ ${ }^{1}$ Department of Aquaculture, Faculty of Marine Sciences and Technology, Çanakkale Onsekiz Mart University, 17100, Çanakkale, Turkey. \\ ${ }^{2}$ Department of Food Technology, Çanakkale School of Applied Sciences, Çanakkale Onsekiz Mart University, 17100 Çanakkale, Turkey \\ ${ }^{*}$ Corresponding author

\begin{tabular}{|c|c|}
\hline A R T I C L E I N F O & A B S T R A C T \\
\hline $\begin{array}{l}\text { "This study was presented as an oral } \\
\text { presentation at the 4th International } \\
\text { Anatolian Agriculture, Food, } \\
\text { Environment and Biology Congress } \\
\text { (Afyonkarahisar, TARGID 2019) } \\
\text { Research Article }\end{array}$ & $\begin{array}{l}\text { In this study, antioxidant activities of two macroalgae, Eucheuma sp. J.Agardh and Laminaria sp., } \\
\text { J.V.Lamouroux used as food supplements were investigated. The antioxidant activity, free radical } \\
\text { scavenging activity, the total content of phenolics, flavonoids and condensed tannins in extracts were } \\
\text { determined. The IC } 50 \text { values of the extracts of Eucheuma sp. and Laminaria sp. on DPPH scavenging } \\
\text { activity was } 2.26 \pm 0.03 \mathrm{mg} / \mathrm{g} \text { and } 2.63 \pm 0.03 \mathrm{mg} / \mathrm{g} \text { of extract, respectively. The maximum total } \\
\text { phenolic ( } 5.31 \pm 0.04 \mathrm{mg} \text { GAE/g Ext.) were determined. According to our results, all extracts } \\
\text { exhibited low radical scavenging activity when compared to the standards used, i.e. } \alpha \text {-tocopherol } \\
\text { and butylated hydroxytoluene (BHT) with the inhibition percentage in the range of } 48.45 \pm 0.06 \% \\
\text { (Eucheuma sp.) - } 58.49 \pm 0.03 \% \text { (Laminaria sp.). The highest flavonoid content was measured as } \\
18.78 \pm 0.10 \mathrm{mg} \text { rutin/g of extract in Laminaria sp. The condensed tannins were not detected in } \\
\text { Eucheuma sp. However, this value was measured as } 6.24 \pm 0.60 \mathrm{mg} \text { CE/g of extract for Laminaria } \\
\text { sp. According to our results, Eucheuma sp. and Laminaria sp., which are commercially sold in } \\
\text { medicinal herb stores, are good sources of antioxidant components because of their phenolic and } \\
\text { flavonoid contents. }\end{array}$ \\
\hline
\end{tabular}

Flavonoids

Laminaria sp.

Phenolics

ilknurak@comu.edu.tr

https://orcid.org/0000-0002-0233-0025

|b@gulenturker@hotmail.com

https://orcid.org/0000-0002-7554-1544

This work is licensed under Creative Commons Attribution 4.0 International License

\section{Introduction}

Macroalgae or seaweeds are photosynthetic organisms and they are renewable resources in the marine environment (Chandini et al., 2008). They are also rich for bioactive compounds (such as protein, essential fatty acids, carbohydrates, vitamins, and minerals) and they can be used for direct human consumption or processed into food additives, pharmaceuticals, feeds, fertilizers, biofuels and cosmetics etc. (Pomponi, 1999; Ak et al., 2015; Pereira, 2018; Kumar et al., 2019). The cultivation of these photosynthetic organisms has accelerated for the last 50 years due to the high demand in the food and pharmaceutical industries. According to FAO statistics (FAO, 2018), 96\% of seaweed is produced via aquaculture while only $4 \%$ of seaweed is harvested. About seven seaweed genera are intensively cultivated such as Eucheuma sp., Kappaphycus sp. Doty, Gracilaria sp. Greville, Laminaria sp., Undaria sp. Suringar, Pyropia sp.
J.Agardh and Sargassum sp. C.Agardh (Buschmann et al., 2017). Among this genus, Laminaria sp. accounts for over $33 \%$ of global cultivated seaweed production, followed by Eucheuma sp. at $17 \%$ of total production (FAO, 2018).

Laminaria is a brown algae genus, which lives along rocky coastal seashores (Margulis and Chapman, 2009). And, Laminaria sp. are common species of kelp that inhabits temperate and cold waters in the northern hemisphere and temperate waters in the southern hemisphere (Kim and Bhatnagar, 2011). This brown seaweed is an excellent source of dietary fibers (over $50 \%$, mainly alginic acid, fucoidan, and laminarin), vitamins (A, C, D, B1, B2, B3, B6, B12, E, K), minerals (K, Na, Ca, $\mathrm{Mg}, \mathrm{I}, \mathrm{S}, \mathrm{Si}$, etc.) and proteins and has been used in agriculture, food, feed, pharmaceutical and cosmetic industries (Kim et al., 2010). Also, East Asian cultures have traditionally exploited Laminaria for food and medicinal 
values (Kim and Bhatnagar, 2011). Laminaria species, especially L. japonica Areschoug and L. saccharina (L.) J.V.Lamouroux has been traditionally used in southeast countries as medicine to treat goiter, scrofula, urinary disease, dropsy, cancer, stomach ailments, and hemorrhoids (Chengkui and Junfu, 1984; Seok et al., 2015). In our country, people prefer this brown seaweed as a vitamin and mineral source. The red seaweed Eucheuma sp. is an economically important tropical seaweed, which is highly demanded its cell wall polysaccharides (Kumar et al., 2008). This macro alga naturally found the Philippines, Indonesia and the island coasts of East Africa (Ask and Azanza, 2002). Also, this red seaweed is cultivated for its hydrocolloids (Santos, 1989). In addition, it contains high amounts of dietary fibers, minerals, vitamins, antioxidants, polyphenols, phytochemicals, proteins, and polyunsaturated fatty acids (Matanjun et al., 2009; Balasubramaniam et al., 2016; Wardani et al., 2017). Eucheuma species traditionally used in Chinese herbal medicine to treat goiter, cough, bronchitis, tonsillitis, asthma with excessive phlegm, stomach ailments, hemorrhoids and anal fistulas (Chengkui and Junfu, 1984). This red seaweed is used as a cough suppressant by Turkish people.

Reactive oxygen species (ROS) or other free radicals are generated continuously via normal physiological processes (Raja et al., 2016; Sevindik, 2019). Under external stimulations (e.g., ionizing radiation, certain pollutants, organic solvents, pesticides etc.), the levels of reactive species can increase dramatically, and they can cause irreversible oxidative damage to all cellular components such as proteins, lipids, amino acids and DNA (Karawita et al., 2005; Tierney et al. 2013; Vasconcelos et al., 2018). The oxidative damages cause aging and many other diseases such as diabetes, arthritis, atherosclerosis, and cancers (O’Sullivan et al. 2011; Tierney et al. 2013; Zhang et al. 2017; Sevindik, 2018). ROS reacts with lipids, proteins, sugars, and vitamins and changes their functionalities (Choe and Min, 2006). In addition, ROS can aggravate the oxidative deterioration and decrease the shelf life of foods (Cox et al., 2010; Choe, 2017). Antioxidants delay the oxidative stress and neutralize free radicals (Sindhi et al., 2013; Pisoschi and Pop, 2015; Sevindik et al., 2018). Seaweeds have polyphenolic compounds such as phenols, flavonoids and condensed tannins which can behave as can behave metal chelators, enzyme modulators and can improve the internal antioxidant system under stress environmental conditions (Duan et al., 2006; Matanjun et al., 2009; Cox et al., 2010; Choe, 2017; JerezMartel et al., 2017; Ismail, 2017; Ak and Türker, 2018). Recently, researchers have focused on to find new and effective antioxidant anti-inflammatory and anticancer compounds in seaweeds. Among them, antioxidant activity is intensively studied due to the current growing demand from the pharmaceutical industry where they are interested in antiaging and anti-carcinogenic compounds, which possess health benefits (Raja et al., 2016).

In Turkey, interest in seaweed has been increasing in recent years. These photosynthetic organisms are consumed as a source of vitamins and minerals as well as medicinal herbs. There are no studies to determine the antioxidant properties of these products sold in herbal stores. The aim of the present study is to evaluate the antioxidant activity and biochemical characteristics of the dried thallus of Eucheuma sp. and Laminaria sp., which are recently used by Turkish people as food supplements and medicinal herbs. We also used correlation to estimate and compare the contribution of polyphenolic compounds to the measured antioxidant activities.

\section{Materials and Methods}

\section{Chemicals}

All reagents used were of analytical grade. All chemicals were purchased from Sigma-Aldrich (USA), SPA (Milan, Italy), Merck (Germany), and Fluka Chemie (Switzerland).

\section{Algal Samples}

In the present study, algal products from Eucheuma sp. and Laminaria sp. were analyzed. Dried Eucheuma sp. and capsuled Laminaria sp. were purchased in medicinal herb stores. Seaweeds were homogenized (IKA, Germany) to a particle size of $1 \mathrm{~mm}$ and stored in glass bottles in a dry, dark environment.

\section{DPPH Free Radical Scavenging Activity Assay}

The free-radical-scavenging activity of the extracts was determined by the DPPH assay as described by BrandWilliams et al. (1995). A $0.06 \mathrm{mM}$ solution of DPPH in methanol was prepared and an aliquot of $100 \mathrm{~L}$ of the antioxidant/seaweed extract solution was added to $3.9 \mathrm{ml}$ of the DPPH solution. The ability of the samples to scavenge DPPH radical was evaluated by measuring the decrease in absorbance (Abs) at $515 \mathrm{~nm}$ using UV-Vis spectrophotometer (Thermo Aquamate). The absorbance of DPPH solution in methanol, without any antioxidant (control), was also measured. The percentage of DPPH radical scavenging $(\%)$ activity was calculated by the following equation:

$$
\mathrm{DPPH}=\left[\left(\mathrm{A}_{\text {control }}-\mathrm{A}_{\text {sample }}\right) / \mathrm{A}_{\text {control }}\right] \times 100
$$

where A sample is the absorbance of the sample after the time necessary to reach the plateau (30 min) and A control is the absorbance of DPPH. Extract concentrations providing $\mathrm{IC}_{50}$ inhibition values (defined as the concentration of the compounds that was able to inhibit $50 \%$ of the total DPPH radicals) were calculated from graph plotting using nonlinear regression.

\section{Determination of Total Phenolic Contents}

The amount of total phenolics was determined with the Folin-Ciocalteu reagent using the method of Djeridane et al. (2006). A standard curve was plotted using gallic acid as a standard. Different concentrations of gallic acid were prepared in $80 \%$ of methanol, and their absorbances were measured at $765 \mathrm{~nm}$. Samples were dissolved with the Folin-Ciocalteu in distilled water. The solutions were mixed. And, then they incubated at room temperature for 1 min. After $1 \mathrm{~min}, 20 \%$ sodium carbonate $\left(\mathrm{Na}_{2} \mathrm{CO}_{3}\right)$ solution was added. The final mixture was shaken and then it was incubated for $2 \mathrm{~h}$ in the dark at room temperature. The absorbance of all samples was measured at $760 \mathrm{~nm}$ using UV-Vis spectrophotometer (Thermo Aquamate) and the results are expressed in $\mathrm{mg}$ of gallic acid per g (GEA) of the dry weight of seaweed. 


\section{Determination of Total Flavonoid Contents}

The flavonoid content was estimated according to Quettier- Deleu et al. (2000). $1 \mathrm{~mL}$ of methanolic extract solution was added to $1 \mathrm{~mL}$ of $2 \%$ methanolic $\mathrm{AlCl}_{3}, 6 \mathrm{H}_{2} \mathrm{O}$. The absorbance was measured $10 \mathrm{~min}$ later at $430 \mathrm{~nm}$. The results were expressed in $\mathrm{mg}$ rutin/100 $\mathrm{g}$ dry matter by comparison with standard rutin treated in the same conditions.

\section{Determination of Condensed Tannin Contents}

Condensed tannin content was evaluated according to Price et al., (1978). An aliquot of $0.5 \mathrm{~g}$ of the seaweed extracts was placed in centrifuge tubes and $20 \mathrm{~mL}$ of $1 \%$ $\mathrm{HCl}$ in methanol was added to each sample. Then, the tubes were placed in a water bath at $30^{\circ} \mathrm{C}$ with constant shaking for $20 \mathrm{~min}$. After incubation, the samples were centrifuged. Aliquots of the supernatants were placed in two separate assay tubes, one for the sample determination and the other for blank determination. Samples and blanks were incubated for exactly $20 \mathrm{~min}$ after adding $5 \mathrm{ml}$ of the vanillin reagent to the samples and $4 \% \mathrm{HCl}$ in methanol to the blanks. Afterward, the absorbance was measured at 500 $\mathrm{nm}$ using a UV-Vis spectrophotometer (Thermo Aquamate). The results were expressed as microgram catechin equivalents per gram of seaweed $(\mu \mathrm{g} \mathrm{CE} / \mathrm{g})$.

\section{Results and Discussion}

The results of the scavenging activity of two edible seaweeds on DPPH free radical are given in Table 1. Laminaria sp. displayed the highest antioxidant potential with a low the half-maximal inhibitory concentration $\left(\mathrm{IC}_{50}\right)$. But, this value was significantly higher than commercial antioxidants tested (Table 1). Statistical significant differences were determined among the comparing groups $(\mathrm{P}<0.05)$. The highest Inhibition \% value was calculated in Laminaria sp. as $58.49 \pm 0.03 \%$ $(\mathrm{P}<0.05)$. Our findings showed that both Eucheuma sp. and Laminaria sp. have high potential DPPH radical scavenging activity.

The polyphenolic compounds such as phenolics, flavonoids, and tannins show antioxidant properties (Duan et al., 2006; Mohammed et al., 2018). Among these compounds, phenolics are dominant in algae and they are one of the most potent antioxidant sources (Cox et al., 2010; Machu et al., 2015). The total phenolic content of two edible seaweed was analyzed using the FolinCiocalteu reagent. The obtained results together with statistical evaluation are presented in Table 2. Specifically, the highest total phenolic content was determined in the brown seaweed Laminaria sp. (5.31 $\pm 0.04 \mathrm{mg} \mathrm{GAE} / \mathrm{g}$ Ext). Also, quite high values were found in the red seaweed Eucheuma sp. (4.16 $\pm 0.03 \mathrm{mg} \mathrm{GAE} / \mathrm{g} \mathrm{Ext})$. According to Student $t$-test results, statistically significant differences were found between two groups $(\mathrm{P}<0.05)$. The high scavenging activity of Laminaria sp. may be due to hydroxyl groups existing in the phenolic compounds. We couldn't properly compare our results with other studies because researchers used different methods of extractions for example; methanol-chloroform extract of L. japonica contained 0.3 mg GAE /g (Zhang et al., 2007), ethanolwater extract of Laminaria digitata (Hudson) J.V.Lamouroux $37.00 \mathrm{mg}$ GAE /g (Heffernan et al., 2015), methanol extract of Eucheuma/Kappaphycus $1.5 \mathrm{mg}$ GAE/g (Ganesan et al., 2008) and $160 \%$ methanol extract of Eucheuma cottonii Weber Bosse $3.96 \mathrm{mg}$ GAE /g (Damongilala et al., 2013). Also, the characteristics of the samples could affect the phenolic content because all mentioned studies were done with fresh samples contrary to the processed seaweeds analyzed in this work.

Flavonoids play an important role in defense systems of seaweeds are the largest group of polyphenolic compounds and they show antioxidant properties by metal chelation (Goiris et al., 2012). Also, they have been associated with reducing the risk of major chronic diseases (Manach et al., 2004). Therefore, the total flavonoid content of two seaweed extracts was estimated by aluminum chloride method (Quettier- Deleu et al., 2000). The total flavonoid contents of Eucheuma sp. and Laminaria sp. were $16.85 \pm 0.11$ and $18.78 \pm 0.10 \mathrm{mg}$ rutin $/ \mathrm{g}$ of extract, respectively. The flavonoid contents of Laminaria sp. was significantly higher than Eucheuma sp. $(\mathrm{P}<0.05)$. This variation in flavonoid content may be due to the algae classes and environmental conditions. According to Farasat et al. (2014), the same species were from the same collection season, had a different level of flavonoid contents. Our results showed that Laminaria sp. could be a good candidate for flavonoid sources.

Table 1 The DPPH radical scavenging activities of Eucheuma sp. and Laminaria sp. Different lowercase letters show the significant differences between the groups according to the ANOVA results $(\mathrm{P}<0.05)$.

\begin{tabular}{l|cl}
\hline \multicolumn{1}{c|}{ Species } & IC $_{50}$ inhibition values $(\mathrm{mg} / \mathrm{g}$ Ext.) & Inhibition \% \\
\hline Eucheuma $\mathrm{sp}$. & $2.63 \pm 0.03^{\mathrm{a}}$ & $48.45 \pm 0.06^{\mathrm{c}}$ \\
Laminaria sp. & $2.26 \pm 0.03^{\mathrm{b}}$ & $58.49 \pm 0.03^{\mathrm{b}}$ \\
Butylated hydroxytoluene & $1.33 \pm 0.01^{\mathrm{d}}$ & $99.00 \pm 0.11^{\mathrm{a}}$ \\
$\alpha$-tocopherol & $1.48 \pm 0.02^{\mathrm{c}}$ & $96.00 \pm 0.15^{\mathrm{a}}$ \\
Vitamin C & $1.35 \pm 0.02^{\mathrm{d}}$ & $98.00 \pm 0.10^{\mathrm{a}}$ \\
\hline
\end{tabular}

Table 2 The total phenolic, flavonoid, and condensed tannin of Eucheuma sp. and Laminaria sp. Different lowercase letters show the significant differences between the groups according to the Student's $t$-test results $(\mathrm{P}<0.05)$.

\begin{tabular}{l|ccc}
\hline \multicolumn{1}{c|}{ Species } & $\begin{array}{c}\text { Total Phenolic } \\
\text { (mg GAE /g Ext.) }\end{array}$ & $\begin{array}{c}\text { Total Flavonoid } \\
\text { (mg rutin/g Ext.) }\end{array}$ & $\begin{array}{c}\text { Condensed Tannin } \\
\text { (mg CE/g Ext.) }\end{array}$ \\
\hline Eucheuma sp. & $4.16 \pm 0.03^{\mathrm{b}}$ & $16.85 \pm 0.11^{\mathrm{b}}$ & $0.07 \pm 0.01^{\mathrm{b}}$ \\
Laminaria sp. & $5.31 \pm 0.04^{\mathrm{a}}$ & $18.78 \pm 0.10^{\mathrm{a}}$ & $6.24 \pm 0.60^{\mathrm{a}}$ \\
\hline
\end{tabular}




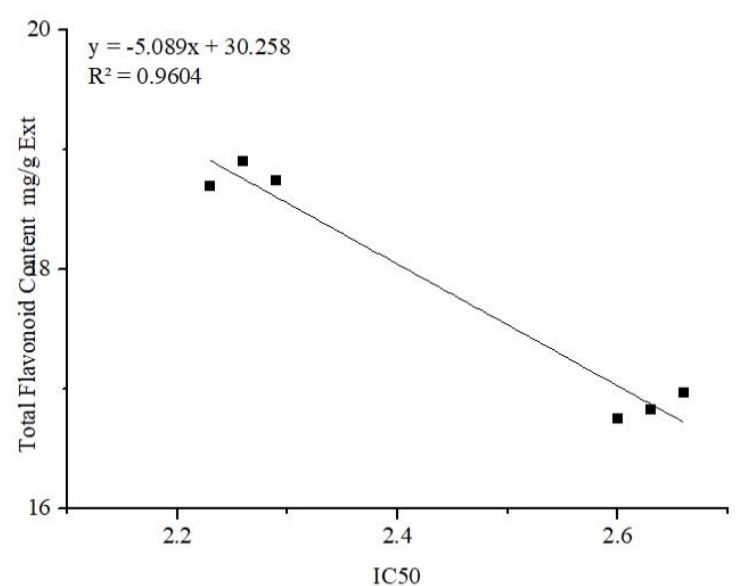

(a)

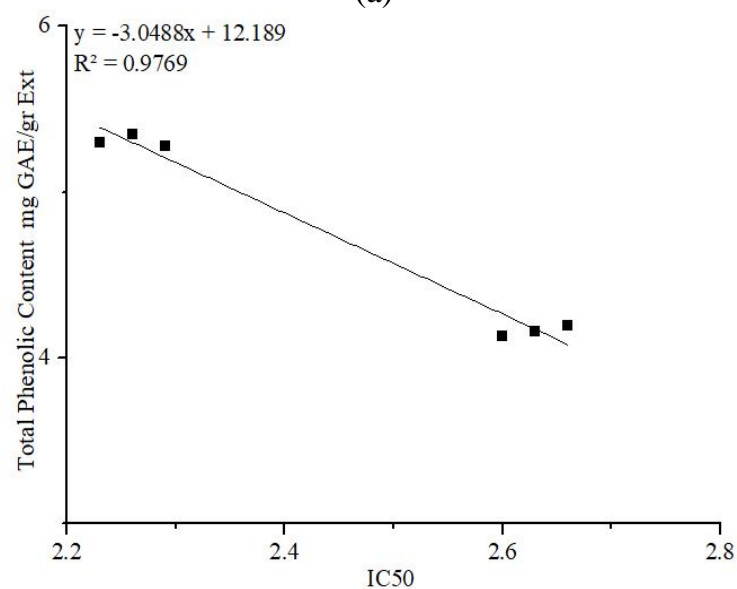

(b)

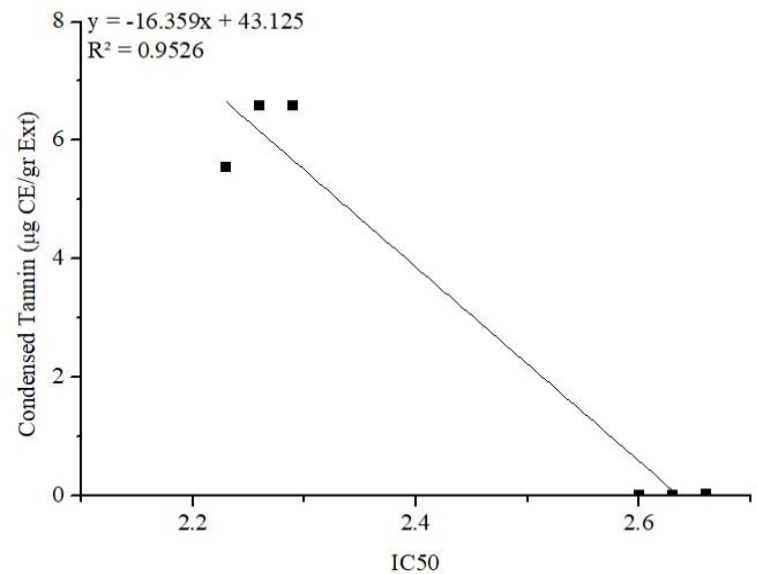

(c)

Figure 1 Correlation graphs for $\mathrm{IC}_{50}$ values and (a) total flavonoid contents, (b) total phenolic contents, (c) condensed tannin contents in two edible seaweeds.

Tannins are naturally occurring polyphenolic compounds and they are secondary plant metabolites (Mueller-Harvey, 2006; Zubek et al., 2012). The total condensed tannin content of Eucheuma sp. and Laminaria sp. can be seen in Table 2. Condensed tannins of the studied seaweeds ranged from $0.07 \pm 0.01$ to $6.24 \pm 0.60 \mathrm{mg}$ $\mathrm{CE} / \mathrm{g}$ of extract. The content of condensed tannins from Laminaria sp. was significantly higher than Eucheuma sp. $(\mathrm{P}<0.05)$. Many studies have shown that phlorotannins are the only phenolic group detected in brown algae (Jormalainen and Honkanen, 2004; Koivikko et al., 2007). Our results show a similarity with these studies.
Because of some similarities in results, statistical correlations between $\mathrm{IC}_{50}$ and the amount of phenolic, flavonoid, condensed tannin compounds have been investigated. According to our findings, the phenolic, flavonoid, and condensed tannin contents were significantly correlated to $\mathrm{IC}_{50}$ inhibition values. As can be seen in Figure 1, all evaluations show significant relationships. The same correlation of antioxidant activity was reported Chakraborty et al., (2013) and Ismail (2017) with some edible brown, green, and red seaweeds of rich polyphenolic content.

\section{Conclusion}

Seaweeds are not only a good source of carbohydrates, proteins, vitamins, oils, polyunsaturated fatty acid, and minerals, but also contain a large concentration of antioxidants compounds such as polyphenols which deserve attention because of the many health benefits they provide (Wells et al., 2017). In this study, we found that seaweed products also have considerable amounts of polyphenolic compounds, which are comparable to polyphenolic compounds in unprocessed seaweeds. The results clearly showed that two edible seaweeds have antioxidant activity with low $\mathrm{IC}_{50}$ inhibition values. We conclude that the main contributors of antioxidant activity these two seaweeds according to a significant negative correlation between $\mathrm{IC}_{50}$ inhibition values and total phenolic, flavonoid, and condensed tannin contents. Therefore, polyphenols, in these two edible seaweeds, appear to not be the major contributors to the high scavenging activities. However, this needs to be determined other active components such as lowmolecular-weight polysaccharides, proteins, peptides, amino acids and essential fatty acids in extracts may have synergistic effects on the scavenging activities, which can give contradictory results. According to our results, Eucheuma sp. and Laminaria sp., which are commercially sold in medicinal herb stores, are good sources of antioxidant components because of their phenolic and flavonoid contents.

\section{References}

Ak I, Öztaşkent C, Özüdoğru Y, Göksan T. 2015. Effect of sodium acetate and sodium nitrate on biochemical composition of green algae Ulva rigida. Aquacult Int. 23(1):1-11. DOI: 10.1007/s10499-014-9793-3.

Ak I, Türker G. 2018. Antioxidant properties and phytochemicals of three brown macroalgae from the Dardanelles (Çanakkale) Strait. Agricultural Science and Technology. 10(4): 354-357. DOI: $10.15547 /$ ast.2018.04.065

Ask EI, Azanza RV. 2002. Advances in cultivation technology of commercial eucheumatoid species: a review with suggestions for future research. Aquaculture 206(3-4):257-277. DOI: 10.1016/S0044-8486(01)00724-4

Balasubramaniam V, Lee JC, Noh MFM, Ahmad S, Brownlee IA, Ismail A. 2016. Alpha-amylase, antioxidant, and antiinflammatory activities of Eucheuma denticulatum (N.L. Burman) F.S. Collins and Hervey. Journal of Applied Phycology. 28(3): 1965- 1974. DOI: 10.1007/s10811-015-0690-6

Brand-Williams W., Cuvelier M.E., Berset C. (1995). Use of a free radical method to evaluate antioxidant activity. LWT Food Sci. Technol., 28(19): 25-30. DOI: 10.1016/S00236438(95)80008-5 
Buschmann AH, Camus C, Infante J, Neori A, Israel Á, Hernández-González MC, Pereda SV, Gomez-Pinchetti JL, Golberg A, Tadmor-Shalev N, Critchley AT. 2017. Seaweed production: overview of the global state of exploitation, farming and emerging research activity. European Journal of Phycology. 52(4): 391-406 DOI: 10.1080/09670262.2017. 1365175

Chakraborty K, Praveen N, Vijayan KK, Rao GS. 2013. Evaluation of phenolic contents and antioxidant activities of brown seaweeds belonging to Turbinaria spp. (Phaeophyta, Sargassaceae) collected from Gulf of Mannar. Asian Pacific Journal of Tropical Biomedicine, 3(1): 8-16. DOI: 10.1016 /S2221-1691(13)60016-7.

Chandini SK, Ganesan P, Bahskar N. 2008. In vitro antioxidant activities of three selected brown seaweeds of India. Food Chemistry 107(2): 707 - 713. DOI: 10.1016/j.foodchem. 2007.08.081

Chengkui Z, Junfu Z. 1984. Chinese seaweeds in herbal medicine. Eleventh International Seaweed Symposium: Proceedings of Eleventh International Seaweed Symposium, 19-25 June 1983, Qingdao, People's Republic of China. DOI: 10.1007/978-94-009-6560-7.24

Choe E. 2017. Effect and mechanisms of minor compounds in oil on lipid oxidation. Ed. Akoh CC, In: Food Lipids: Chemistry, Nutrition, and Biotechnology. CRC Press.Boca Raton, Fourth Edition. ISBN: 978-1-4987-4485-0 pp:567-590.

Choe E, Min D. 2006. Chemistry and reactions of reactive oxygen species in foods. Journal of Food Science. 70(9): $142-159$. DOI: 10.1111/j.1365-2621.2005.tb08329.x

Cox S, Abu-Ghannam N, Gupta S, 2010. An assessment of the antioxidant and antimicrobial activity of six species of edible Irish seaweeds. International Food Research Journal, 17: 205 - 220. DOI: 10.21427/D7HC92

Damongilala LJ, Widjanarko SB, Zubaidah E, Runtuwene MRJ. 2013. Antioxidant Activity Against Methanol Extraction of Eucheuma cotonii and E. spinosum Collected From North Sulawesi Waters, Indonesia. Food Science and Quality Management. 17: 13. DOI:10.7176/FSQM

Djeridane A, Yousfi M, Nadjemi B, Boutassouna D, Stocher, Vidal N. 2006. Antioxidant activity of some Algerian medicinal plants extracts containing phenolic compounds. Food Chem. 97:654-660. DOI: 10.1016/j.foodchem. 2005.04.028

Duan XJ, Zhang WW, Li XM, Wang BG. 2006. Evaluation of antioxidant property of extract and fractions obtained from a red alga, Polysiphonia urceolata. Food Chemistry 95: 37-43. DOI: $10.1016 /$ j.foodchem.2004.12.015

FAO. 2018. The global status of seaweed production, trade and utilization. Globefish Research Programme Volume 124 Rome 120 pp.

Ganesan P, Kumar CS, Bhaskar N. 2008. Antioxidant properties of methanol extract and its solvent fractions obtained from selected Indian red seaweeds. Bioresource Technology, 99(8): 2717-2723. DOI:10.1016/j.biortech.2007.07.005

Goiris K, Muylaert K, Frayee I, Foubert I, De Brabanter J, De Cooman L. 2012. Antioxidant potential of microalgae in relation to their phenolic and carotenoid content. J Appl Pyhcol 24:1477-1486. DOI: 10.1007/s10811-012-9804-6

Heffernan N, Smyth TJ, Soler-Villa A, Fitzgerald RJ, Brunton NP. 2015. Phenolic content and antioxidant activity of fractions obtained from selected Irish macroalgae species. Journal of Applied Phycology. 27(1): 519 - 530. DOI: $10.1111 /$ ijfs. 12512

Ismail GA. 2017. Biochemical composition of some Egyptian seaweeds with potent nutritive and antioxidant properties. Food Science and Technology. 37(2): 294-302. DOI:10.1590/1678-457X.20316

Jormalainen V. Honkanen T. 2004. Variation in natural selection for growth and phlorotannins in the brown alga Fucus vesiculosus. Journal of Evolutionary Biology 17 (4): 807-820. DOI: DOI: 10.1111/j.1420-9101.2004.00715.x
Jerez-Martel I, Garcia-Poza S, Rodriguez-Martel G, Rico M, Afonso-Olivares C, Gomez-Pinchetti JL. 2017. Phenolic profile and antioxidant activity of crude extracts from microalgae and cyanobacteria strains. Hindawi Journal of Food Quality. 2017:1-8. DOI: 10.1155/2017/2924508

Karawita R, Siriwardhana N, Lee KW, Heo MS, Yeo IK, Lee YD, Jeon YJ. 2005. Reactive oxygen species scavenging, metal chelation, reducing power and lipid peroxidation inhibition properties of different solvent fractions from Hizikia fusiformis. Eur Food Res Technol 220:363-371. DOI: 10.1007/s00217-004-1044-9

Kim HW, Choi JH, Choi YS, Han DJ, Kim HY, Lee MA, Kim SY, Kim CJ. 2010. Effects of sea tangle (Laminaria japonica) powder on quality characteristics of breakfast sausages Korean J. Food Sci. Anim. Res., 30 (2010), pp. 55-61.

Kim SW, Bhatnagar I. 2011. Physical, chemical, and biological properties of wonder kelp-Laminaria. In: Marine Medicinal foods: Implications and applications, macro and microalgae. Ed. Kim SW. Academic Press. Elsevier, Waltham, ISBN: 978-0-12-387669-0. pp:85-96.

Koivikko R, Loponen J, Pihlaja K, Jormalainen V. 2007. Highperformance liquid chromatographic analysis of phlorotannins from the brown alga Fucus vesiculosus. Phytochemical Analysis 18 (4): 326-332. DOI: 10.1002 /pca.986

Kumar CS, Ganesan P, Suresh PV, Bhaskar N. 2008. Seaweeds as a source of nutritionally beneficial compounds, a review. Journal of Food Science Technology 45:1-13.

Kumar J, Khan A, Mandotora SK, Dhar P, Tayade AB, Verma S, Toppo K, Arora R, Upreti DK, Chaurasie OP. 2019. Nutraceutical profile and evidence of alleviation of oxidative stress by Spirogyra porticalis (Muell.) Cleve inhabiting the high altitude Trans-Himalayan Region. Scientific Reports 9:4091. DOI: 10.1038/s41598-018-35595-x

Machu L, Misurcova L, Ambrozova JV, Orsavova J, Mlcek J, Schor J, Jurikova T. 2015. Phenolic Content and Antioxidant Capacity in Algal Food Products. Molecules 20:1118-1133, DOI: $10.3390 /$ molecules20011118

Manach C, Scalbert A, Morand C, Rémésy C, Jiménez L. 2004. Polyphenols: Food sources and bioavailability. Am. J. Clin. Nutr. 79(5):727-747. DOI: 10.1093/ajcn/79.5.727

Matanjun P, Mohamed S, Mustapha NM, Muhammad K. 2009. Nutrient content of tropical edible seaweeds, Eucheuma cottonii, Caulerpa lentillifera and Sargassum polycystum. J Appl Phycol. 21(1):75-80. DOI: 10.1007/s10811-008-9326-4

Margulis L, Chapman MJ. 2009. Kingdoms and Domains (Fourth Edition). Academic Press. Elsevier. New York. ISBN: 978-012-373621-5. Pp: 117-230. DOI: https://doi.org/10.1016 /B978-0-12-373621-5.X0001-3

Mohammed FS, Akgul H, Sevindik M, Khaled BMT. 2018. Phenolic content and biological activities of Rhus coriaria var. zebaria. Fresenius Environmental Bulletin 27(8): 56945702.

Mueller-Harvey I. 2006. Unravelling the conundrum of tannins in animal nutrition and health. Journal of the Science of Food and Agriculture, 86(13): 2010-2037.DOI: 10.1002/jsfa.2577

O'Sullivan AM, O'Callaghan YC, O'Grady MN, Queguineur B, Hanniffy D, Troy DJ, Kerry JP, O’Brien NM. 2011. In vitro and cellular antioxidant activities of seaweed extracts prepared from five brown seaweeds harvested in spring from the west coast of Ireland. Food Chem 126(3):1064-1070. DOI: 10.1016/j.foodchem.2010.11.127

Pisoschi AM, Pop A. 2015. The role of antioxidants in the chemistry of oxidative stress: A review. European Journal of Medicinal Chemistry. 97:55-74. DOI: 10.1016 /j.ejmech.2015.04.040

Pereira L. 2018. Seaweeds as Source of Bioactive Substances and Skin Care Therapy-Cosmeceuticals, Algotheraphy, and Thalassotherapy. Cosmetics 5(4): 68; DOI: 10.3390 /cosmetics5040068 
Price ML, Vanscoyoc S, Butler LG. 1978. Critical evaluation of Vanillin reaction as an assay for tannin in sorghum grain. $\mathrm{J}$. Agric. Food Chem. 26(5):1214-1218. DOI: 10.1021/ jf60219a031

Pomponi SA. 1999. The bioprocess-technological potential of the sea. J. Biotechnol. 35: 5-13. DOI: 10.1016/S0079-6352 (99)80092-7

Raja R, Hemaiswarya S, Arunkumar K, Carvalho IS. 2016. Antioxidant activity and lipid profile of three seaweeds of Faro, Portugal. Braz. J. Bot 39(1):9-17. DOI: 10.1007 /s40415-015-0200-8

Seok S, Kim TS, Kwon HJ, Lee SP, Kang MH, Kim BJ, Kim MN. 2015. Efficacy of Cistanche tubulosa and Laminaria japonica extracts (MK-R7) supplement in preventing patterned hair loss and promoting scalp health. Clin Nutr Res. 4(2): 124131. DOI: $10.7762 / \mathrm{cnr} .2015 .4 .2 .124$

Sevindik M. 2019. The novel biological tests on various extracts of Cerioporus varius. Fresenius Environmental Bulletin 28(5): 3713-3717.

Sevindik, M. 2018. Investigation of oxidant and antioxidant status of edible mushroom Clavariadelphus truncatus. Mantar Dergisi 9(2): 165-168.

Sevindik M, Akgul H, Dogan M, Akata I, Selamoglu Z. 2018. Determination of antioxidant, antimicrobial, DNA protective activity and heavy metals content of Laetiporus sulphureus. Fresenius Environmental Bulletin 27(3): 1946-1952.

Quettier-Deleu C, Gressier B, Vasseur J, Dine T, Brunet J, Luyck M, Cazin M, Cazin JC, Bailleul F, Trotin F. 2000. Phenolic compounds and antioxidant activities of buckwheat (Fagopyrum esculentum Moench) hulls and flour. J. Ethnopharmacol. 72(1-2):35-40. DOI: $10.1016 / \mathrm{S} 0378-8741(00) 00196-3$

Santos, GA. 1989. Carrageenans of species of Eucheuma J.Agardh and Kappaphycus Doty (Solieriaceae, Rhodophyta).Aquat. Bot.36(1): 55-67. DOI: 10.1016/03043770(89)90091-0

Sindhi V, Gupta V, Sharma K, Bhatnagar S, Kumari R, Dhaka N. 2013. Potential applications of antioxidants - A review. Journal of Pharmacy Research. 7: 828 - 835. DOI: 10.1016/j.jopr.2013.10.001
Tierney MS, Smyth TJ, Hayes M, Soler-Vila A, Croft AK, Brunton N. 2013. Influence of pressurized liquid extraction and solid-liquid extraction methods on the phenolic content and antioxidant activities of Irish macroalgae. Int. J. Food Sci. Technol. 48:860-869. DOI: 10.1111/ijfs.12038

Wardani G, Farida N, Andayani R, Kuntoro M, Sudjarwo SA. 2017. The Potency of Red Seaweed (Eucheuma cottonii) Extracts as Hepatoprotector on Lead Acetate-induced Hepatotoxicity in Mice. Pharmacognosy Res. 9(3): 282 - 286. DOI: 10.4103/pr.pr_69_16 PMID: 28827971

Wells ML, Potin P, Craigie J.S, Raven JA, Merchant SS, Helliwell KE, Smith AG, Camire ME, Brawley SH. 2017. Algae as nutritional and functional food sources: Revisiting our understanding. J. Appl. Phycol. 29(2):949-982. DOI: 10.1007/s10811-016-0974-5

Vasconcelos JB, de Vasconcelos ERTPP, Urrea-Victoria V, Bezerra PS, Reis TNV, Cocentino ALM, Navarro DMAF, Chow F, Areces AJ, Fuji MT. 2018. Antioxidant activity of three seaweeds from tropical reefs of Brazil: potential sources for bioprospecting. Journal of Applied Phycology. DOI: 10.1007/s10811-018-1556-5

Zhang WW, Duan XJ, Huang HL, Zhang Y, Wang BG. 2007. Evaluation of 28 marine algae from the Qingdao coast for antioxidative capacity and determination of antioxidant efficiency and total phenolic content of fractions and subfractions derived from Symphyocladia latiuscula (Rhodomelaceae). J. Appl. Phycol. 19(2):97-108. DOI: 10.1007/s10811-006-9115-x

Zhang Y, Unnikrishnan A, Deepa SS, Liu Y, Li Y, Ikeno Y, Sosnowska D, Remmen HV, Richardson A. 2017.A new role for oxidative stress in aging: the accelerated aging phenotype in mice is correlated to increased cellular senescence. Redox Biol 11:30-37. DOI: 10.1016/j.redox.2016.10.014

Zubek S, Mielcarek S, Turnau K. 2012. Hypericin and pseudohypericin concentrations of a valuable medicinal plant Hypericum perforatum L. are enhanced by arbuscular mycorrhizal fungi. Mycorrhiza, 22(2): 149-156.DOI: 10.1007/s00572-011-0391-1 